\title{
SPECIES COMPOSITION, ABUNDANCE, DISTRIBUTION AND HABITAT ASSOCIATION OF RODENTS OF WONDO GENET, ETHIOPIA
}

\author{
Dawit Kassa and Afework Bekele * \\ Department of Biology, Faculty of Science, Addis Ababa University, PO Box 1176, \\ Addis Ababa, Ethiopia. E-mail: afeworkbekele@hotmail.com
}

\begin{abstract}
A study on small mammal community of Wondo Genet was carried out from August, 2005 to March, 2006 encompassing both wet and dry seasons. This was undertaken using both livetrapping and snap-trapping techniques in farmlands, plantations, grasslands, forest and bushes. There were 371 captures of rodents and shrews from live-trapping and 73 captures from snaps. Seven species of rodents (Stenocephalemys albipes, Lophuromys flavopunctatus, Arvicanthis abyssinicus, Desmomys harringtoni, Mastomys natalensis, Mus mahomet and Rattus rattus) and two species of shrews (Crocidura flavescens and C. fumosa) were recorded. S. albipes and L. flavopunctatus were the most abundant species, whereas M. mahomet, $R$. rattus, C. flavescens and C. fumosa were rare. Males comprised $55 \%$ and females $45 \%$ of the total capture. Among the rodents captured, $76.8 \%$ were adults, $3.6 \%$ sub-adults and $19.6 \%$ young. Estimates of population size on the live trapping grids using minimum number alive (MNA) technique varied from 59 in January to 103 in November. Peak density was recorded for S. albipes (226/ha) and lowest for $R$. rattus (16/ha). Maximum biomass was recorded during November (5,256 g) and minimum during January $(2,314 \mathrm{~g})$. Most of the rodents in the present study tended to prefer bushes and scrubs.
\end{abstract}

Key words/phrases: Abundance, distribution, rodents, Wondo Genet

\section{INTRODUCTION}

The geographical position, range of altitude, rainfall pattern and soil variability of Ethiopia have resulted in an immense ecological diversity and huge wealth of biological resources. The flora of Ethiopia is very heterogeneous and diverse with an estimated number between 6,500 to 7,000 species of higher plants, of which about 12 percent is endemic. The country is also rich in its faunastic diversity. About 284 species of mammals, 861 species of birds, 201 species of reptiles, 63 species of amphibians, 145 species of fresh water fish, 324 species of butterflies are known from Ethiopia. There are at least 31 species of endemic mammals in Ethiopia. Among these, five are larger mammals and the rest are smaller ones including 2, 9 and 15 species of bats, insectivores and rodents, respectively (www. chroa. virtu. lave. net).

The order Rodentia is the most numerous among the mammalian orders. Currently, there are 29 living families, 468 genera, and roughly 2052 species of rodents (Nowak, 1999). According to Vaughan et al. (2000), rodents are diverse and remain today very successful. Rodents retain large, untapped stocks of genetic variability inhabiting diverse habitats. This variability is exposed to the

\footnotetext{
* Author to whom all correspondence should be addressed.
}

selective forces of evolution as rodents produce large litters within few months.

Rodents range in size from pygmy mice weighing $5 \mathrm{~g}$ to capybaras, the largest of which weigh over $70 \mathrm{~kg}$. However, rodents show less overall variation in body plan than do members of many other mammalian orders. The body build of most rodents is that of conventional quadruped but evolution and adaptations have resulted in burrowing, bounding, climbing and gliding forms with specific structural developments (Kingdon, 1997).

The Ethiopian rodent fauna comprises 30 percent of the total mammalian fauna of the country (Hillman, 1993). Out of the 84 species of rodents recorded from Ethiopia, 15 are endemic, contributing $50 \%$ of the total endemic mammalian fauna of the country. Among the nine families of Ethiopian rodents, the Family Muridae comprises $81 \%$ of the species and $93 \%$ of the endemic rodents (Afework Bekele, 1996b; Afework Bekele et al., 1999). Among the species of insectivores in Ethiopia, the shrews (Family Soricidae) are among the smallest of mammals with wide distribution.

Given the large number of species, there are only few reports on the Ethiopian rodents (Yalden et al., 1976; Müller, 1977; Rupp, 1980; Yalden, 1988; Afework Bekele et al., 1993, 1999; Afework Bekele, 
1995; 1996a, 1996b; Sillero-Zubri et al., 1995; Afework Bekele and Corti, 1997; Afework Bekele and Leirs, 1997; Lavrenchenko et al., 1998). There are still many regions of Ethiopia yet to be studied for this species composition and distribution of small mammal fauna. An ecological assessment of rodents and shrews based on trapping in different habitats of Wondo Genet was undertaken during the present investigation.

\section{The study area}

The present investigation was carried out in Wondo Genet, geographically located between $7^{\circ} 5.9^{\prime}-7^{\circ} 6^{\prime} \mathrm{N}$ latitudes, and $38^{\circ} 37^{\prime}-38^{\circ} 37.8^{\prime} \mathrm{E}$ longitudes, which is part of the Wondo Genet College of Forestry (Fig. 1). Wondo Genet is located $264 \mathrm{~km}$ south of Addis Ababa and $14 \mathrm{~km}$ southeast of Shashemene. It is located within the Ethiopian Rift Valley of the Southern Nations Nationalities and People's Region (snnpr), Sidama Zone. The altitude ranges between $1,800 \mathrm{~m}$ and 2,100 $\mathrm{m}$ above sea level (asl). Wondo Genet has a bimodal rainfall distribution with two rainy seasons. Short rains occur during March-May and the long rains in July-October (Fig. 2). The dry season extends from November to February.

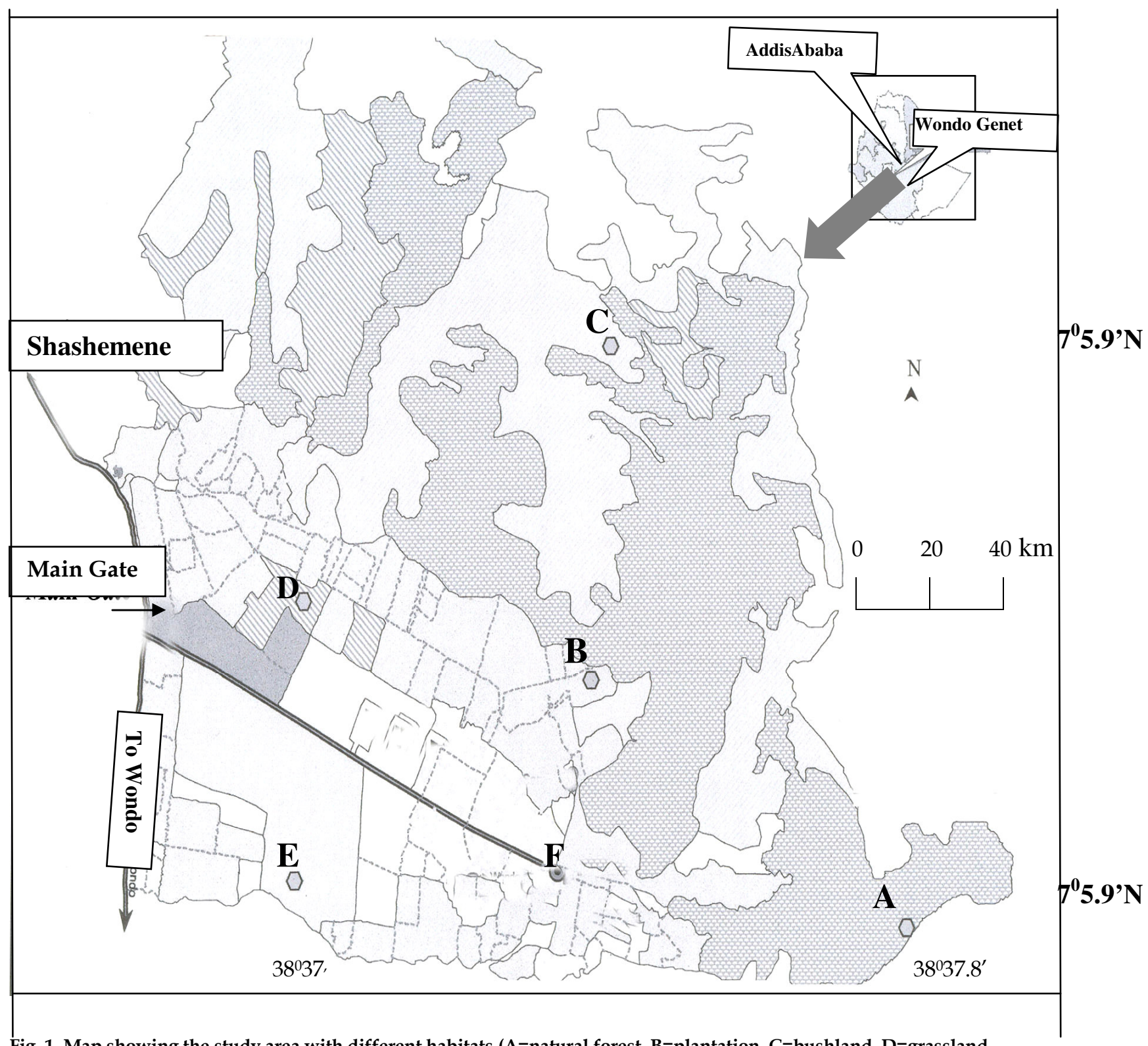

Fig. 1. Map showing the study area with different habitats $(A=$ natural forest, $B=$ plantation, $C=$ bushland, $D=$ grassland, $E=$ farmland) and office (F). 


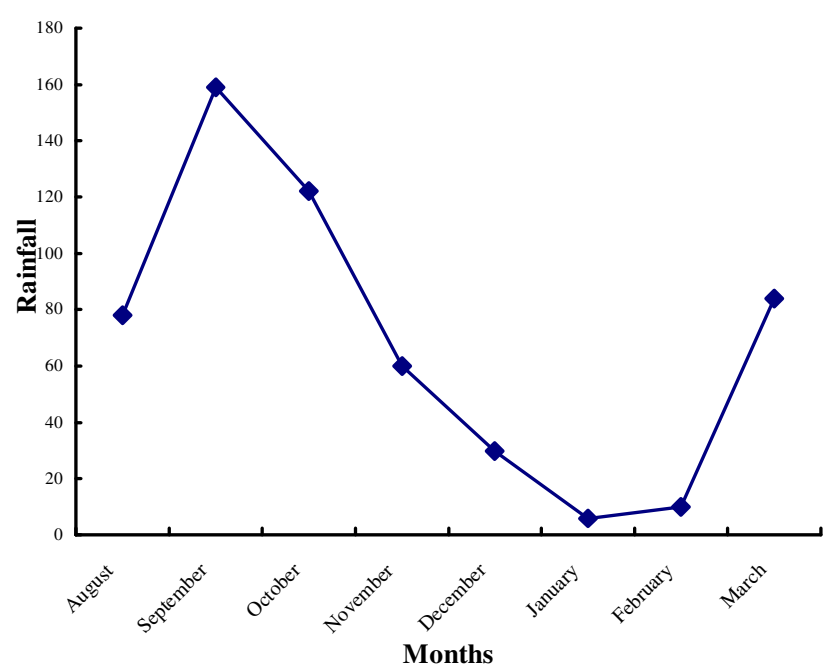

Fig. 2. Monthly rainfall during the study period (August, 2005March, 2006).

\section{Habitat description}

Five different habitat types were randomly selected for the present investigation based on the nature and composition of the plant species. These are:

A. Natural forest above $1,900 \mathrm{~m}$ asl with mixed dense canopy;

B.Plantation area at $1,890 \mathrm{~m}$ asl grouped into two major parts;

1. Exotic species (Eucalyptus sp., Cupressus lusitanica, Pinus patula, Grevia robusta);

2. Indigenous species (Juniperus procera, Podocarpus falcatus, Olea africana, Hagenia abyssinica and Cordia africana);

C. Bushes and scrubs at 2,100 $\mathrm{m}$ asl

D. Grassland at $1,800 \mathrm{~m}$ asl

E.Farmland at 1,800 masl, predominantly maize fields.

\section{MATERIALS AND METHODS}

The study was undertaken during August, 2005 March, 2006, covering both wet and dry seasons.
Both live-trapping and snap-trapping techniques were employed in each of the representative habitat sites (natural forest, plantation, bush, farmland and rock piles) to compare whether there are differences in the preference of traps.

Five separate live-trapping grids, each of 70x70 $\mathrm{m}$, representing the five habitat types (A-E) were established for capture-mark-recapture study. A single grid was set up in each of the representative sites of the habitat during the study periods. Each of the grids consisted of 7x7 lines at $10 \mathrm{~m}$ intervals. A total of 49 Sherman traps were placed in each grid. Peanut butter and barley flour were used as bait during all trapping sessions. Trapping was conducted for three consecutive days in each habitat during each of the trapping sessions.

Five transects, one transect per habitat, were laid for snap trapping in each study period. A total of 25 snap traps was placed at $10 \mathrm{~m}$ intervals in each habitat, $100 \mathrm{~m}$ away from the live trapping grids. Trapping was carried out for three consecutive days in each habitat. Density and biomass were estimated on a seasonal basis.

Data analysis was carried out using SPSS version 12.0. Shannon-Wiener Diversity Index $\left(\mathrm{H}^{\prime}\right)$ was used to estimate species diversity and Simpson's Similarity Index (SI) was used to compare the small mammal composition among habitats.

\section{RESULTS}

A total of seven rodent species belonging to the Family Muridae were trapped during the entire trapping sessions. These were Stenocephalemys albipes, Lophuromys flavopunctatus, Arvicanthis abyssinicus, Desmomys harrigntoni, Mastomys natalensis, Mus mahomet and Rattus rattus. In addition to this, two shrew species, Crocidura flavescens and Crocidura fumosa were captured during the study periods (Table 1).

Table 1. Species composition, distribution and abundance of rodent and insectivore species in different habitats (figures in brackets indicate recaptures, - indicates absence of capture).

\begin{tabular}{lllllll}
\hline Species & Natural Forest & Plantation & Bushland & Grassland & Farmland & Total Capture \\
\hline $\mathrm{Sa}$ & $29(9)$ & $14(3)$ & $48(9)$ & $17(4)$ & $4(1)$ & 138 \\
$\mathrm{Lf}$ & $38(4)$ & $12(3)$ & $40(16)$ & $14(3)$ & $3(2)$ & 135 \\
$\mathrm{Aa}$ & - & - & $26(6)$ & $13(1)$ & $11(3)$ & 60 \\
$\mathrm{Dh}$ & $16(1)$ & 1 & $18(5)$ & $2(1)$ & $1(1)$ & 46 \\
$\mathrm{Mn}$ & $6(2)$ & $2(1)$ & $13(4)$ & $5(3)$ & $11(7)$ & 54 \\
$\mathrm{Mm}$ & $6(2)$ & $7(4)$ & 2 & - & - & 21 \\
$\mathrm{Rr}$ & 5 & $1(1)$ & - & - & $2(1)$ & 10 \\
$\mathrm{Cfl}$ & - & - & - & - & 2 & 2 \\
$\mathrm{Cfu}$ & - & - & - & - & 2 & 2 \\
\hline
\end{tabular}

Note: $\mathrm{Sa}=S$. albipes, $\mathrm{Lf}=L$. flavopunctatus, $\mathrm{Aa}=A$. abyssinicus, $\mathrm{Dh}=\mathrm{D}$. harringtoni, $\mathrm{Mn}=\mathrm{M}$. natalensis, $\mathrm{Mm}=\mathrm{M}$. Mahomet, $\mathrm{Rr}=R$. rattus, $\mathrm{Cfl}=\mathrm{C}$. flavescens, and $\mathrm{Cfu}=\mathrm{C}$. fumosa 


\section{Live trapping}

A total of 468 captures (including recaptures) of 371 individuals were made in 3675 trap nights during the five trapping sessions. Of these, 112 $(30.2 \%)$ were S. albipes, $107 \quad(28.8 \%)$ L. flavopunctatus, $50(13.5 \%)$ A. abyssinicus, 38 (10.2\%) D. harringtoni, 37 (10.0\%) M. natalensis, 15 (4.0\%) M. mahomet, $8(2.2 \%)$ R. rattus, $2(0.5 \%)$, C. flavescens and $2(0.5 \%) \quad$ C. fumosa. S. albipes and $L$. flavopunctatus were the dominant and most common species. Trap success at different sites and occasions varied from $6.9 \%$ to $25.4 \%$ with the mean $12.7 \%$.

The number of individuals captured from bushes and shrubs (147) was higher than those from natural forest (100), herbaceous grassland (51), plantation (37) and farmland (32). The overall difference in abundance of rodents among the habitats was significant $\left(\chi^{2}=131.67, P<0.001\right)$. Among the seven species of rodents, six were trapped from the natural forest, plantation, bushes, farmland and five from grassland.

Most of the rodent species and individuals were trapped from bushes during both seasons. There was no significant difference among the captures between species and season $\left(\chi^{2}=8.050, \mathrm{P}=0.234\right)$. However, the difference in the number of individual rodents between wet and dry seasons was significant $\left(\chi^{2}=22.56, \mathrm{P}<0.001\right.$ (Table 2$)$.

Of the total 367 individual rodents captured, males comprised 201(55\%) and females 166 (45\%). There was no significant difference in the sex ratio $\left(\chi^{2}=33.33, P>0.05\right)$. However, the sex ratio was $1: 1$ during the wet season and 0.63:0.37 during the dry season with a high statistical difference $\left(\chi^{2}=9.16\right.$, $\mathrm{P}<0.01)$. Young animals accounted for $19.6 \%$ of the total capture. Thirteen $(30.6 \%)$ of the captured rodents were sub-adults. A total of $282(76.8 \%)$ adults were captured during the entire trapping sessions.
Table 2. Abundance of rodents during wet and dry seasons.

\begin{tabular}{llll}
\hline \multirow{2}{*}{ Species } & \multicolumn{2}{c}{ Season } & \multirow{2}{*}{ Total } \\
& 75 & 37 & 112 \\
\hline S. albipes & 70 & 37 & 107 \\
L. flavopunctatus & 25 & 25 & 50 \\
A. abyssinicus & 26 & 12 & 38 \\
D. harringtoni & 22 & 15 & 37 \\
M. natalensis & 8 & 7 & 15 \\
M. mahomet & 3 & 5 & 8 \\
R. rattus & $239(62)$ & $138(38)$ & $367(100)$ \\
Total $(\%)$ & & & \\
\hline
\end{tabular}

The highest density was recorded for $S$. albipes (226/ha) and lowest for $R$. rattus (16/ha) during the entire trapping sessions (Table 3 ). Peak density occurred in November (194/ha) and the lowest during January (82/ha). The maximum biomass was recorded during November $(5,257 \mathrm{~g})$ and the minimum during January $(2,314 \mathrm{~g})$. The biomass of rodents during the wet season $(12,202 \mathrm{~g})$ was greater than that of the dry season $(7,570.69 \mathrm{~g})$ with a high statistical difference $\left(\chi^{2}=10.83, P<0.001\right)$.

\section{Snap trapping}

A total of 73 individual rodents were snap trapped during 1500 trap nights, with only 4.9\% trap success. Six species were captured: S. albipes, $L$. flavopunctatus, M. natalensis, A. abyssinicus, D. harringtoni and $R$. rattus (Tables 4 and 5). The natural forest yielded the highest catch followed by bushes and crevices. Diversity Indices were 1.545, 1.508, 1.490, 1.424 and 2.410 for bushes, natural forest, farmland, grassland and plantation, respectively. The Simpson's Similarity Index indicates that the similarity of species composition among the five habitats was 0.69 .

Table 3. Density of species (number of individuals/ha) in each grid.

\begin{tabular}{lllllllll}
\hline Grid & \multicolumn{9}{c}{ Species } & Total \\
\cline { 2 - 7 } & Sa & Lf & Aa & Dh & Mn & Mm & $\mathrm{Rr}$ & \\
\hline Natural forest & 58 & 76 & - & 32 & 12 & 12 & 10 & 200 \\
Plantation & 28 & 24 & - & 2 & 4 & 14 & 2 & 74 \\
Bushland & 98 & 81 & 52 & 36 & 26 & 4 & - & 297 \\
Grassland & 34 & 28 & 26 & 4 & 10 & - & - & 102 \\
Farmland & 8 & 6 & 22 & 2 & 22 & - & 4 & 64 \\
Total & 226 & 215 & 100 & 76 & 74 & 30 & 16 & 737 \\
\hline
\end{tabular}

Note: $\mathrm{Sa}=S$. albipes, $\mathrm{Lf}=\mathrm{L}$. flavopunctatus, $\mathrm{Aa}=A$. abyssinicus, $\mathrm{Dh}=\mathrm{D}$. harringtoni, $\mathrm{Mn}=\mathrm{M}$. natalensis, $\mathrm{Mm}=\mathrm{M}$. Mahomet, $\mathrm{Rr}=R$. rattus 
Table 4. Species composition and abundance of snap trapped rodents (- indicates absence of species).

\begin{tabular}{|c|c|c|c|c|c|}
\hline \multirow[t]{2}{*}{ Species } & \multicolumn{5}{|c|}{ Trapping month } \\
\hline & Sep. & Nov. & Jan. & March & Total \\
\hline $\mathrm{Sa}$ & 6 & 3 & 3 & 3 & 15 \\
\hline Lf & 14 & 10 & 8 & 9 & 41 \\
\hline Aa & 1 & 2 & 1 & - & 4 \\
\hline $\mathrm{Dh}$ & 1 & - & - & - & 1 \\
\hline $\mathrm{Mn}$ & 2 & 3 & 3 & 3 & 11 \\
\hline $\mathrm{Rr}$ & 1 & - & - & - & 1 \\
\hline Total & 25 & 18 & 15 & 15 & 73 \\
\hline
\end{tabular}

Note: $\mathrm{Sa}=S$. albipes, $\mathrm{Lf}=L$. flavopunctatus, $\mathrm{Aa}=A$. abyssinicus, $\mathrm{Dh}=D$. harringtoni, $\mathrm{Mn}=M$. natalensis, $\mathrm{Mm}=M$. Mahomet, $\mathrm{Rr}=R$. rattus

Table 5. Distribution and abundance of snap trapped rodents.

\begin{tabular}{|c|c|c|c|c|c|c|c|}
\hline \multirow{2}{*}{ Habitat } & \multicolumn{7}{|c|}{ Species } \\
\hline & Lf & Sa & $\mathrm{Mn}$ & Aa & Dh & $\mathrm{Rr}$ & Total \\
\hline Natural forest & 15 & 6 & 2 & - & 1 & 1 & 25 \\
\hline Plantation & 4 & 1 & - & - & - & - & 5 \\
\hline Bushland & 10 & 6 & 2 & 3 & - & - & 21 \\
\hline Farmland & 5 & - & 1 & - & - & - & 6 \\
\hline Rock piles & 7 & 2 & 6 & 1 & - & - & 16 \\
\hline Total & 41 & 15 & 11 & 4 & 1 & 1 & 73 \\
\hline
\end{tabular}

Note: $\mathrm{Lf}=L$. flavopunctatus, $\mathrm{Sa}=S$. albipes, $\mathrm{Mn}=M$. natalensis, $\mathrm{Aa}=A$. abyssinicus $\mathrm{Dh}=D$. harringtoni, $\mathrm{Rr}=\mathrm{R}$. rattus

\section{DISCUSSION}

Mean trap success of $12.7 \%$ obtained during the present study was very low compared to similar studies elsewhere in Ethiopia (Table 6). One of the reasons for low trap success might be due to high human interference in the area. In addition, grazing by livestock resulted in less ground cover especially during the dry season. Yalden (1988) recorded similar low trapping success in the Erica forest disturbed by human habitation and highest trap success in the undisturbed Erica scrub above the disturbed zone in the Bale Mountains. Happold (1978) emphasized the unusually low number of Praomys tulbergi in Nigerian forest, affected by human interference. The other reason for low trap success in the study area was the reduced monocot vegetation, as monocot seeds are highly favoured by rodents. Bush habitat revealed high species number and abundance during the entire trapping sessions. The reason for this might be due to the hospitability of medium sized trees and other vegetation as food, cover and domicile. Natural forest had the second highest population size during the entire trapping session. The dense patches of heterogeneous vegetation might be a suitable habitat as domiciles and dry season refugia for shelter seeking rodents during the harsh season of the year. At the same time, $M$. Mahomet was not trapped using snap traps. This might be due to the small size of the species weighing about $12 \mathrm{~g}$.

The first dry season (November) was ideal for most rodents and the short rainy season (March) for reproductive activity. Rodents might have preferred moderate rainfall and a slightly warmer to moderate temperature for their reproductive activities. Flowers and seeds in this habitat were common at the beginning of the first dry season. It is known that the abundance of rodents would be high during the reproductive phase of vegetation in the habitat (Workineh Gebresilassie et al., 2004).

Table 6. Species composition and mean trap success of rodents carried out by different researchers in different parts of Ethiopia.

\begin{tabular}{llcl}
\hline Place & Number of species & Mean trap success (\%) & Researcher \\
\hline Western Ethiopia & 10 & 35.0 & Rupp (1980) \\
Bale Mountains & 7 & 18.7 & Yalden (1988) \\
Menagesha Forest & 6 & 9.1 & Afework Bekele (1996) \\
Entoto Natural Park & 9 & 62.8 & Bekele Tsegaye (1999) \\
Allelitu Woreda & 3 & 8.4 & Manyingrew Shenkut (2004) \\
Alatish National Park & 23 & 38.6 & Tadesse Habtamu (2005) \\
\hline
\end{tabular}


The main reason for high population size $(62 \%)$ during the wet season as compared to low (38\%) during the dry season was breeding, nutrition, and environmental factors. Most of the rodents in the present study sites tended to prefer bushes. Although there are differences in abundance, the Simpson's Similarity Index revealed that there is high similarity in the species composition of small mammals among the different habitat types in Wondo Genet.

\section{ACKNOWLEDGEMENTS}

We wish to thank the Department of Biology, Addis Ababa University for funding the project and Wondo Genet College of Forestry for providing additional facilities.

\section{REFERENCES}

1. Afework Bekele (1995). Post-natal development and reproduction in captive bred Praomys albipes (Mammalia: Rodentia) from Ethiopia. Mammalia 59:109-118.

2. Afework Bekele (1996a). Population dynamics of the Ethiopian endemic rodent Praomys albipes in the Menagesha State Forest. J. Zool., Lond. 238:1-12.

3. Afework Bekele (1996b). Rodents of the Menagesha State Forest, Ethiopia, with an emphasis on the endemic Praomys albipes Rüppell 1842. Tropical Zoology 9:201-212.

4. Afework Bekele and Corti, M. (1997). Forest blocks and altitude as indicators of Myomys albipes (Rüppell, 1842) (Mammalia: Rodentia) distribution in Ethiopia. Tropical Zoology 10:287293.

5. Afework Bekele, Corti, M., Capanna, E., Marcus, L.F. and Schlitter, D.A. (1993) Systematic and geographic variation of Ethiopian Arvicanthis (Rodentia: Muridae). J. Zool., Lond.230:117-134.

6. Afework Bekele, Corti, M., Scanzani, A., Rossi, A.R., Civitelli, M.V. and Capana, E. (1999). Karyotypic and genetic divergence in the Ethiopian Myomys-Stenocephalemys complex (Mammalia: Rodentia). Ital. J. Zool. 66:341-349.

7. Afework Bekele and Leirs, H. (1997). Population ecology of rodents of maize fields and grassland in central Ethiopia. Belg. J. Zool. 127:39-48

8. Bekele Tsegaye (1999). Species composition, distribution and population dynamics of rodents of Entoto Natural Park. MSc thesis, Addis Ababa University, Addis Ababa.

9. Happold, D.C.D. (1978). Reproduction, growth and development of a West African forest mouse, Praomys tulbergi (Thomas). Mammalia 42:73-96.

10. Hillman, J.C. (1993). Ethiopia: A Compendium of Wildlife Conservation Information. New York Zoological Society and Ethiopian Wildlife Conservation Organization. Addis Ababa.

11. Kingdon, J. (1997). The Kingdon Field Guide to African Mammals. Academic Press, San Diago.

12. Lavrenchenko, L.A., Likhnova, O.P., Baskevich, M.I. and Afework Bekele (1998). Systematics and distribution of Mastomys (Muridae: Rodentia) from Ethiopia, with the description of a new species. Z. Saugetierkunde 63:37-51.

13. Manyingerew Shenkut (2004). Distribution and abundance of rodents in different crops in Allelitu Wereda, Oromia Region, Ethiopia. MSc Thesis, Addis Ababa University, Addis Ababa.

14. Müller, V.J.P. (1977). Population Okologie von Arvicanthis abyssinicus in der Grassteppe des Semien Mountains National Park (Äthiopien). Z. Saugetierkunde 42:145-172.

15. Nowak, R.M. (1999). Walker's Mammals of the World. $6^{\text {th }}$ ed. John Hopkins University Press, Baltimore, London.

16. Rupp, H. (1980). Beirage Zur systematic, Verbreitung und okologie athiopischer Nagetiere: Ergeb. Mehr. Forchung. Saugetierk. Mitt. 28:81-123.

17. Sillero-Zubiri, C., Tattersall, F.M. and Macdonald, D.W. (1995). Bale Mountains rodent communities and their relevance to the Ethiopian wolf (C. simensis). Afr. J. Ecol. 83:301320.

18. Vaughan, T.A., Ryan, J.M. and Czaplewiski, N.J. (2000). Mammalogy. Fourth Edition. Saunders College Publishing, Philadelphia.

19. Workneh Gebresilassie, Afework Bekele, Gurja Belay and Balakrishnan, M. (2004). Microhabitat choice and diet of rodents in Maynugus irrigation field, northern Ethiopia. Afr. J. Ecol., 42:315-321.

20. w.w.w. chora. virtu. lave.net. IBCR. Home page. Institute of Biodiversity Conservation and Research. December 19, 2005.

21. Yalden, D.W., Largen, M.J. and Kock, D. (1976). Catalogue of the mammals of Ethiopia 2. Insectivora and Rodentia. Mon. Zool. Ital. (N.S.) 8:1-118.

22. Yalden, D.W. (1988). Small mammals in the Harena Forest, Bale Mountains National Park. SINET: Ethiop. J. Sci. 11:41-53. 